\title{
THE LABOR MARKET IN THE CONDITIONS OF A PANDEMIC CRISIS
}

\author{
Venelin Terziev ${ }^{1}$, Nikolay Ninov ${ }^{2}$, Ivan Ivanov ${ }^{3}$ \\ ${ }^{1}$ Full Member of the Russian Academy of Natural History, Professor, Eng., D.Sc. (National \\ Security), D.Sc. (Economics), D.Sc. (Social Activities), Ph.D. \\ Russian Academy of Natural History, Moscow, Russia \\ Georgi Rakovski Military Academy, Sofia, Bulgaria \\ University of Rousse, Rousse, Bulgaria \\ Kaneff University Hospital, Rousse, Bulgaria \\ vkterziev@gmail.com \\ ${ }^{2}$ Associate Professor, Ph.D., D.A. Tsenov Academy of Economics, Svishtov, Bulgaria \\ n.ninov@uni-svishtov.bg \\ ${ }^{3}$ Ph.D., Kaneff University Hospital, Ruse, Bulgaria, \\ isivan@abv.bg
}

\begin{abstract}
This publication amalyzes and examines the changes in the labour market during the pandemic crisis and their impact on the healthcare system in Bulgaria. The object of the study is the social protection system and employment of the population in Bulgaria.

The theoretical and methodological foundations of the study lie in its complex and systematic approaches. Moreover, the complex interdisciplinary approach, involving the integration of sociological, theoretical and managerial, socio-economic and other aspects of the study are related to systems analysis.
\end{abstract}

Keywords: healthcare system, labour market, pandemic crisis, social policies.

\section{INTRODUCTION}

The relevance of the researched topic is conditioned by the fact that social management plays an increasing and determining role in Bulgaria. It practically affects all spheres of life of our society. We are in the middle of a smooth modernization of the insufficiently effective social and political system of the country, which is being carried out with the help of the programme-target approach.

We associate every form of human activity with anticipating some specific actions of making sense of it in some way, i.e. as a specific programme. This is even more important when it comes to organizing and coordinating joint actions and activities, managing the overall activity in social communities, starting with the smallest and ending with the national ones.

Justified social norms and decisions and programmes containing the final result, i.e. the goal, and the way to achieve it, i.e. the methods and procedures for carrying out the respective activity, give the opportunity to influence the processes purposefully, comprehensively and systematically.

The object of the study is the social protection system and employment of the population in Bulgaria.

The subject of the study is an assessment of changes and dynamics of the labour market during the pandemic crisis and their impact on the healthcare system in Bulgaria. 
The theoretical and methodological foundations of the study lie in its complex and systematic approaches. Moreover, the complex interdisciplinary approach, involving the integration of sociological, theoretical and managerial, socio-economic and other aspects of the study are related to systems analysis.

Methodological foundation of the study is comprised of the fundamental ideas of Bulgarian and foreign sociology about the specifics of social efficiency in the activities of institutional governance subjects, including public authorities. Based on them, social management is considered from the systemic point of view, which means regulating the relationship between the object and the subject of management, as a purposeful impact on the social system in order to bring its functioning and development in line with socially significant goals.

Empirical basis. In addition to the theoretical methods, the authors of the study actively used observation and statistical analysis of the sociological information.

The information sources used in the research project also include archival documents from the Ministry of Labour and Social Policy, the National Employment Service, later known as the Employment Agency, the National Social Welfare Service, later known as the Social Welfare Agency, National Statistical Institute, National Social Security Institute, documents and statistical materials of the bodies for social protection and employment, programmes for social support and employment of the Bulgarian population, materials from the Ministry of Labour and Social Policy, the Employment Agency, the Social Welfare Agency, the National Statistical Institute, social demographic data on the population composition, pupils and students, the professional and qualification structure of the employed and unemployed persons in the country, materials of sociological surveys of the main categories of unemployed working age population, results of expert surveys of managers and specialists from social protection bodies and employment services, special literature on the research topic, materials from the media, materials form conferences, meetings, seminars and round tables on the issues analyzed in the study. Local observations and impressions take a significant place among the information sources, which in combination with statistical materials and expert assessments, allow to compile an objective picture of the analyzed processes and to develop an optimal model for measuring social efficiency of the state employment services: National Employment Agency, "Regional Employment Services" Directorates, Labour Offices Directorates and their affiliates (Terziev, 2020; 2020a; 2020b; 2020c; 2020d).

\section{LABOUR MARKET - CHARACTERISTICS}

The labour market is one of the markets for the factors of production (along with the land market and the capital market). It is a specific mechanism for rational and efficient distribution and use of labour to regulate employment.

The labour maket plays a vital role for the stability of enterprises, for the economic and social development of the country, for high quality of life.

The labour market as one of the main markets has an important role for the sustainable economic and social development of each country and region, for the high quality of life of the population. Its development and conjuncture have a direct impact on the development of organizations and the population. As one of the main markets, its development and state is determined by that of others, but it itself influences other markets in one way or another. The normal functioning of the economy, its dynamics, structure and efficiency predetermine the labour demand in terms of quantity, but also structure, as well as the possible cost of labour. Market economy means that the organizations and the enterprises find and provide themselves with resources, incl. human resources, through the markets and in accordance with the rules, norms, institutions and strategies and policies applied by them. The population, people's income, professional and labour realization depend on the mechanisms that regulate the labour market and on the management of economic activity and public life (Terziev, 2015)..

The labour market is often defined as a set of legal norms, principles, rules, requirements, procedures, institutions and policies that help organizations find the necessary workforce and the working age population to find the desired job (jobs). It is an abstract place where the purchase and sale of the commodity "labour" takes place, where the transaction between the sellers and the buyers of labour takes place. It takes place when there is a real labour supply and demand and the price of labour is determined by the ratio between them. It is a kind of mechanism for distribution of the labour force, regulator of its movement, that predetermines the level of employment and unemployment and determines the price of different types of labour.

The labour market is a dynamic system in which the supply and demand for labour, employees and employers interact. The main components of the labour market are demand and supply of workforce and 
labour; workforce and labour; cost of labour; competition between supply and demand for the labour.

Participants of the labour market include employers and their representatives; employees and workers and their representatives (trade unions and/or associations of workers); the state and its bodies (Ministry of Labour and Social Policy and its bodies: agencies, directorates and others directly related to the labour market).

The supply of labour is determined by the expressed willingness and ability of workers with certain quality features to work during a certain period of time at an adequate wages level and other conditions. There is a difference between collective and unitary labour supply. The first is determined by the number of working age population of the country, the development of the economy and its ability to create jobs, the level of education and professional training, the level of wages, the current mechanisms of taxation of the population, motivation to work and others. The unitary supply is determined by the decisions of the household, by its size and structure, by the level of income and the price of free time, by the desire of an individual for professional realization, self-affirmation and respect.

The demand for labour is defined by the expressed willingness and ability of employers to hire a workforce with relevant qualitative and other features, in accordance with the needs of the organization for newly created or temporarily vacated jobs or positions. Collective demand for labour is determined by the development of the economy, the business environment, the nature of economic growth and the level of competitiveness and productivity of production, the level of wages and others. Each employer, each organization individually determines its demand for labour in accordance with the goals and strategy of its development, the level of effective use of the already hired labour force, its investment and marketing strategy, its financial condition, its policy and investments in terms of human resources and other.

Labour market institutions are organizations, units or individuals that in one form or another help those looking for a workforce (employers) find those supplying labour (working age persons).

The unemployment rate is measured and characterized by the economic activity rate. It is defined as the ratio between the number of unemployed and the economically active population.

The higher number of unemployed leads to the decreased economic potential and the limited labour force of the country, one of its most important resources. Therefore, increasing employment is one of the most important goals in the macroeconomic policy of any government, as well as in the strategy of the European Union. Employment is characterized by an employment rate, which is determined by the ratio between the number of employees and the population aged 15 and over. The increase in employment is primarily related to the development of competitive and efficient production, but also to increased access to employment for all groups of the population, to reduced employment in the shadow economy, the economically inactive ("discouraged" and others) and the unemployed and mainly the so-called long-term unemployed, who are sometimes a large part of the unemployed population. This group increases the "price" of unemployment, leads to impoverishment, social isolation and other negative social trends (Terziev, 2015).

Long-term unemployed, according to the national legislation, are the persons (unemployed) who remain registered as unemployed in the labour offices for over 12 months. Similar to it is the indicator of average unemployment, which characterizes the situation on the labour market, the degree of mismatch between supply and demand for labour, in general and in the relevant labour markets.

One of the key features of the unemployed status is that the person is looking for a job and is ready to start work. For this purpose an expression "a person who is actively looking for a job" is used. This is a person who goes to job interviews with potential employers and does not deny such inerviews appointed by the state employment agencies (Recruitment office).

Supply of labour is generally aimed at finding a suitable job. According to the Employment Promotion Act in Bulgaria, a suitable job is one that considers the education, qualification, health status, gender and age of the person and is in the same settlement or at a certain distance from it (for example up to $30 \mathrm{~km}$ outside it), provided that there is adequate public transport. This definition of a suitable job is valid for the unemployed persons who are with such status for up to 12 months after this period, i.e. for the long-term unemployed any work that corresponds to their health condition is considered appropriate.

When unemployment rate is very high, which creates high social tension, and no significant human resources are used, governments implement different policies to increase employment and/or regulate the labour market. The latter involves the use of various measures and incentives known as passive and/or active employment policies. 
The passive labour market policy includes government measures related to unemployment benefits and allowances payment, the establishment and functioning of labour market institutions. The active labour market policy includes measures, programmes and plans aimed at returning the unemployed people to employment, at their inclusion in the labour force (Terziev, 2015).

In times of high unemployment, economic stagnation and crisis, when labour demand is low or insufficient, governments often use various programmes and measures to create temporary jobs. It is the long-term unemployed who mainly benefit from them. In the first place are programmes that create employment in the public sector and/or in various activities of general benefit to society (cleaning, afforestation, etc.). The use of the term "public sector jobs" in this case means the jobs that include municipal activities such as: utility services, development of settlements and industrial areas, maintenance and protection of municipal property, environmental protection, maintenance and protection of historical monuments and sites and so on. Similar programmess have been known for the last twenty years in business activities and in real business organizations. These are the so-called more subsidized employment programmes or subsidized jobs. In recent years, such a programme in Bulgaria is the programme "From social benefits to employment", which is practically a system of private regional programmes. They most often finance the inclusion of the unemployed in such programmes (salary, social security contributions, etc.) from the state budget (or other public resources). With these practically artificially created jobs, unemployment is temporarily reduced, and the long-term unemployed are given the opportunity to return (albeit for a certain period of time) to employment, income and insurance.

In the policies for regulating unemployment and increasing employment, the importance is given to increasing the capacity, the potential of the employed and unemployed through training, raising education and qualification. By definition, "vocational qualification" is training for initial and additional qualification, as well as retraining of working age persons outside the system of education of adolescents.

Changes in employment and unemployment are also related to the seasonality of production and a number of other activities that have limited effect during the year. The term "seasonal work" is used to describe labour that is performed during certain periods of the calendar year and depends on the climate conditions (construction, tourism, agricultural activities, etc.).

Increasing employment and reducing unemployment is also possible by increasing activity and the entrepreneurial spirit of the working age population. Such a form is self-employment, i.e. the independent work of people with the so-called free professions, craftsmen. The term "self-employed person" refers to any person who works for themselves or in a partnership with other people.

Very often the connection between the demand and supply of labour is intermediary, i.e. it is carried out through various institutions (public or private). They provide the so-called "intermediary services" on the labour market, which include activities for informing and hiring unemployed or employed persons looking for a new job, as well as for organizing and conducting professional trainings.

In periods of economic and/or financial crisis, in case of financial or market difficulties of individual organizations, the latter start reducing their employee numbers, initiate minor, considerable or mass layoffs. The term "mass dismissal" refers to the action when within one month an employer terminates the employment contracts of a significant part of the staff (for example, more than 50 persons in a company with over 100 employees or more than half of the employees in an enterprise with a staff of 50 to 100) (Terziev, 2015).

A number of other concepts are used, which characterize the complex and dynamic processes taking place on the labour market and in the field of employment.

The interaction between the two variables - demand for labour and supply of labour, determines the balance of the labour market. The stability of the labour market depends on the competitive nature of this interaction.

The cost of labour plays a determining role in coordinating the plans of job seekers and employers.

The economic process taking place on the labour market substantially affects the relations between those who offer and those who seek labour. This process begins, on the one hand, with the job search by the working age persons, and on the other hand, with the relevant activity of the employer - the enterprise or organization. Once contact between the two parties has been established and employment conditions acceptable to both of them have been agreed, they can sign an employment contract. The service that the employee renders to the employer or the work itself is performed exactly after the contract has been signed.

In many respects, however, the labour market is a specifically functioning market that differs from other 
markets. The main reason is in the nature and peculiarities of the commodities that are sought and offered on the labour market - the "commodity" labour. On the labour market, the employer negotiates with the employee about the service he wishes to be performed. For the performed service the employee receives a certain amount of money agreed in the process of negotiation. It follows that the "commodity" that the worker offers on the labour market is related to his abilities and skills for work, thanks to which under certain conditions, time and remuneration it is possible to perform one service of the employer or another. So what is bought and sold is labour service, not human capital. The abilities of people and human capital belong to the worker, i.e. they are part of him. This is the specific meaning of the "commodities" that are "sold" on the labour market. The subject of a deal concluded on the market is not the worker (human capital), as this would mean his transformation into a commodity (as it was in the period of slavery), but the abilities to work, which the employer uses to achieve their goals - income and profit. By providing their knowledge, skills and creativity the individual at the same time performs a service to the employer for a certain price. In this sense, it is said that what is offered on the market are labour services. In the same sense the term labour is used further on, with the meaning of labour service (Terziev, 2020; 2020a; 2020b; 2020c; 2020d).

There are also differences between the labour market and other markets in terms of the adequacy of prior information. For the employee it is expressed in the discrepancy between the pre-agreed and the actual working conditions and remuneration. For the employer, it is the discrepancy between the preliminary assessment of the employee's qualities and the actual ones. This is one of the reasons why we have a probationary period, during which it is possible to assess whether the previously agreed with the employer price of labour corresponds to the real, and if necessary certain adjustments are made.

Another feature of the labour market is the existence of workers' and employers' organizations. The negotiations between the employee and the employer and the agreement they reach largely depend on the balance of powers of the unions and the employers associations. Unlike other markets, the labour market is characterized by specific legislation. Many of the clauses in the collective labour agreement are regulated and pre-approved by the labour legislation - working conditions and working hours, minimum wage, days off, holidays and others.

The labour market experiences strong state intervention through the implemented measures and programmes within the framework of active and passive policies. The state also intervenes when acute social problems arise on the labour market - low social security, labour discrimination, poverty, unhealthy working conditions and others. Most often, social conflicts and tension in the country are related to labour market problems.

The above features of the labour market do not end there and still give some idea of its versatility and complexity. If we want to summarize, we should emphasize that all these features are interrelated with the nature and characteristics of the specific product "labour", i.e. with the object of "purchase and sale" on the labour market (Terziev, 2020c; 2020d).

\section{DEVELOPMENT AND RESTRUCTURING OF EMPLOYMENT IN BULGARIA}

The reduction of the share of the industrial sector in GDP and in the total employment is a natural process and marks the transition from an industrial to an information society. This radical change in the structure of national economies often leads to a radical change in the professional careers of the employed, to an increase in unemployment and poverty, to escalation of social conflicts. The transition from industrial production to the development of different types of services is difficult and often costly (Terziev, 2015).

Deindustrialization in Bulgaria has a number of specifics in contrast to Western economies; it was determined not so much by the natural course of economic development, but by the political changes and the reforms aimed at transition to a market economy. Thus, the processes of deindustrialization had to solve both economic and political problems: to make the economy efficient and competitive, but at the same time to change its ownership, scale and characteristics. Reforms began with a change of ownership, a reduction in monopolies and environmental pollution, elimination and reduction of inefficient production, and moved on to a functioning market economy that complies with EU policy standards and rules and the requirements of a globalizing economy. These two transitional periods, towards a market economy and towards integration into the EU, have led to a radical restructuring of production and employment. Unlike other countries in Central and Eastern Europe carrying out similar transitions, in Bulgaria these processes had a high social cost and significant consequences for the income of the population, its security and employment.

\subsection{The Legacy for the Beginning of the Transition to a Market Economy}

In the years of socialism, the state policy was aimed at preventing unemployment, which was at the expense 
of economic efficiency and productivity. The authorities were constantly creating new jobs and mobilizing all available labour resources to participate in the production. The massive accumulation of fixed capital and the large investments in the development of the human resources of the country did not contribute to the stable and continuous growth of productivity. The so called "hidden unemployment" was also developing, which was related to the inefficient use of the already employed labour force, loss of working time due to various reasons, low labour intensity and others.

Until the mid 1970s, economic growth was based on a continuous increase in the use of productive resources (labour, investment, raw materials, energy) - proportionally to the growth of production or faster. Long before the end of the 1980s, it became more and more clear - and therefore the question was openly raised that it was not possible to ensure further growth of production in the current extensive way, i.e. by a constant increase in the factors of production. Attempts have been made to move to an intensive type of development by increasing labour productivity in terms of resources used and output. However, the conditions for such development were not created - modernization of production, new technologies and equipment and economic incentives for those employed in productive labour. The slowdown in economic growth in the 1980s due to the retention and decline in labour productivity increased hidden unemployment. This led to serious difficulties in maintaining the living standards of the population.

The managers of the enterprises were also interested in maintaining higher employment than economically necessary. The category of the enterprise and the level of payment depended on its size, incl. the number of its employees. In addition, there was a reserve of manpower that could be used when it was necessary to implement or overfulfill the plan - usually at the end of the year or the five-year plan. The overspending of funds for production, including wages, was not sanctioned.

The distribution of the labour force between the separate branches of activity, sectors and economic regions took place administratively. To the extent that a labour market could be considered to exist under these conditions, it had the following features (especially in the last decade) (Terziev, 2020e; 2020f):

- The demand for labour exceeded the supply, i.e. the number of jobs was more than the number of the working age population;

- High level of employment among the population, incl. women. Practically the whole working age population who did not continue their education in full-time mode and were not in the army, but were healthy, participated in the economy, meaning were employed;

- Relatively low level of wages and insignificant differentiation in the level of wages of different groups of employees (by education, vocational training and qualification, working conditions and other factors that differentiate wages);

- Continuous increase of the educational level and professional training of the employed, mainly at the expense of the younger generations, despite the low pay of the skilled labour, very often lower than the labour of the employed with low education and without professional training;

- Universal and guaranteed employment, a high degree of protection against dismissal, until actually the worker himself wishes to resign;

- Controlled movement of the population and especially of the labour force to big cities,

- Obligatory job placement for higher and other vocational schools graduates (until the beginning of the 80s);

- Significant share and priority of social benefits in the cost of labour and motivation to work in one organization or another such as opportunities for early retirement, protection from dismissal - especially before retirement, before giving birth and mothers with young children, the disabled and others, the provision of housing or dormitories by the enterprise at symbolic prices, paid maternity leave (up until the child turns 3 ) and continuing education while retaining a job, free or relatively low cost meals provided by the enterprises, cheap and annual family vacations at the sea and/or in the mountains, purchase of food and other products from the enterprise at low prices, free use of medical, dental, preventive and sports services in the enterprises, low fees of the kindergartens at the enterprise, scholarships for students who are children of the long-term employees of the organization and others. In the second half of the twentieth century, Bulgaria's economy changed from a typically agricultural to a highly industrial one. In the early 1950s, the predominant share of production and employment was in agricultural sector. The collectivization of agriculture in the 1960 s and the intensive policy of industrialization radically changed the structure of production and employment. More than one million agricultural workers have switched to other sectors, mainly industry and, 
to a much lesser extent, construction and services. The share of industrial production and employment was constantly increasing and at the end of the 1980s the share of industrial production, investments, long-term tangible assets and employment in Bulgaria had the features of a typical industrial economy.

Several years before the beginning of the transition, in accordance with the current then attempts to reform the socialist economy, the distribution of labour and its mobility was freed from administrative intervention. With the transition to a market economy from the very beginning, the movement of the population and the labour force was liberalized - inside and outside the country, between the individual settlements and to the big cities; wages; hiring and firing, etc (Terziev, 2020e; 2020f).

The first half of the 90s was a period of economic reforms: creation and development of markets, incl. labour market; changing the employment model and creating adequate policies to deal with the social problems arising from privatization, structural reforms and the emerging unemployment and impoverishment of the population. A policy of EU integration and related strategic and planned actions to reduce the number of unemployed and increase employment has been pursued since the late 1990s. Strategies have been adopted, incl. Strategy for employment and national plans and for linking economic development with job creation.

The inherited significant and diverse social benefits, which were used by the population during socialism, led to a kind of reversal during the transition. On the one hand, people's expectations that they would be maintained, on the other hand, budgetary constraints, the poor financial condition of enterprises, the uncertainty of the management staff about their and the organization's future proved to be an obstacle to their preservation.

In practice, the costs of these benefits increase the cost of labour, reduce profits, worsen economic conditions of transforming state-owned enterprises, and the start-up small private enterprises lack experience and often a desire or ability to stimulate and motivate staff.

Since 1991 for the first time in the country the negotiation of the salary was introduced - both of the individual and the collective labour relations. A relevant act of the government created three levels of wage formation: national - to determine the minimum wage for the country, the types and minimum amount of additional wages (for long-term work, overtime work, etc.); collective labour agreements - at sectoral and branch level and at enterprise level; individual employment relationship.

On the basis of the legislation and the relevant normative acts, the hiring process changed - through negotiations between the two parties of the employment relationship, instead of unilateral agreement by order of the head of the enterprise. During these years of transition, the existing situation on the labour market predetermined that the employment would take a form of fixed-term employment contracts (with a maximum duration of three years according to the current legislation). The practice and the specific state of the respective labour markets have widely established the short-term labour employment (with a term of up to 1 year), as well as the employment not on the basis of a contract, but on the so-called "Commission agreements", employment without a contract at all or without social security and so on.

The years of transition to a market economy laid the foundations of industrial relations, completely unknown and undeveloped during socialism. Their foundations were laid in the first years (1989-1990) and in the following years they continued to develop and enrich. They legislatively established the principle of tripartism in the management of human resources at the national level, determined the object of tripartite partnership (regulation of labour and social security relations and issues related to living standards), regulated the manner of partnership of the state with representative organizations of the employees (consultations and cooperation), determined the main criteria for the representativeness of the organizations of the employees and the employers (membership, representation of branches, presence of national and regional structures). The institutions of industrial relations in Bulgaria were built. Their main state is the advice for tripartite (in enterprises - bipartite) cooperation. For this purpose, the rich experience of European countries and the relevant conventions and recommendations of the International Labour Organization were used in this regard.

The creation of guarantees for the realization of the fundamental rights of workers requires the preparation and adoption of a number of specific laws, as well as the establishment of the relevant institutions, funds and other conditions on their basis. Because of the impossibility, on the one hand, for the National Assembly to prepare and adopt many laws in the field of labour and social protection of the population for this relatively short period, and, on the other hand, because of the need to adopt a number of laws concerning other spheres of public life during this same period, the respective governments have prepared and adopted a number of by-laws (decrees, ordinances, etc.) in the field of the labour market. In the field of the labour 
market they focused on creation and development of institutions, unemployment insurance and benefits, promotion of incentives for the unemployed and employers to increase employment, training and qualification, etc.; on social security - both for the hired people and for the self-employed, entrepreneurs, freelancers and others; on social assistance and social care; healthcare; education; wages; working conditions and others. Based on them, the relevant institutions were built - with central management and the relevant regional structures (Terziev, 2020e; 2020f).

The development of the labour market follows the main trends in the development of the economy restructuring, privatization, elimination of inefficient productions and activities. Throughout the first period, the supply of labour remained high, whereas the demand was severely limited. This has made low employment and high unemployment a significant social problem for successful EU integration.

Changes in the volume of production affect the level of unemployment and employment.

\section{CHANGES IN THE LABOUR MARKET DURING THE PANDEMIC CRISIS AND THEIR IMPACT ON THE BULGARIAN EDUCATION AND HEALTHCARE SYSTEM IN PARTICULAR}

In the process of the complex market restructuring of the Bulgarian economy since the end of the 1980s, specific conjunctural factors are generated and activated. During the first period, they suppress growth, lead to deterioration and even to individual distortions in some major macroeconomic dependencies and proportions. This period is also characterized by trade and prices liberalization which led to painful longlasting reforms in the agricultural sector.

The quantitative dependence highlights the lagging response to unemployment, which manifests itself in about three times less change in its rate than the relative change in gross product. This is mainly related to the three factors. If interpreted more broadly and updated, these factors reveal some obvious and hidden, indirect signs of unemployment, employment and labour productivity; difficult to overcome discrepancies between statistically reported and actual unemployment rates. These factors include the following more important impacts:

- In cases of a more significant and prolonged decline in production, the process of redundancy of workers is accelerated, although it is possible that this process proceeds with different intensity. The unemployment rate is increasing at a slower pace (not at a similar one), because for various reasons a smaller part of the total number of redundant workers (and not all of them) are additionally included in the group of unemployed.

- Some of the redundant employees turn relatively quickly to self-employment, entrepreneurship (most often in the field of small business), others give up participation in employment, i.e. move to the group of economically inactive people.

- Any more fragile and lasting reduction of production affects the duration, forms and nature of employment. The number of part-time employees is increasing. Due to the fact that the volume of production is decreasing, due to the declining revenues and profits, companies are striving to reduce costs in order to overcome the situation faster. Very often this results in reduced labour productivity and the rate of GDP growth. Part-time employment can be seen both as a form of flexible employment, the realization of the freedom of individuals in terms of their working hours, and as an "intermediate" labour indicator, which is formed at the crossroads between employment and unemployment, because human resources are not fully used, workers receive irregular, significantly smaller and unsatisfactory pay. Thus, although formally employed, some of the employed may also appear as hidden unemployed. In practice, especially during the first transition period, employment in many enterprises did not meet the definition of employment and working hours, labour productivity and wages did not meet established standards. The employment of these people is more limited and more precarious than normal. This happens mainly in cases of deterioration of the general economic pace of development, of production restrictions for individual enterprises (markets, supplies, cooperative supplies, etc.), as a result of which production and financial results deteriorate and the probability of mass layoffs increases (redundancies, dismissals).

Our social system, whether we agree with it or not, is facing a serious challenge in the current crisis situation caused by the COVID 19 pandemic. It has, of course, experienced far more severe challenges, especially in the years of active political and economic transformation after change of the social and political system in the end of the 1990s in Bulgaria. In 1989 and in the following years, it faced extremely severe crises at least a few more times. The cyclical nature of these functioning deformations cannot be justified, but certain groups of factors can be distinguished that to one degree or another affect it. To a large extent, they depended on 
the ability of the economy to withstand or not certain difficulties that occur over a period of time. These difficulties have been offset in some cases of the natural course of certain events and processes, and in other situations a set of corrective measures and programmes have been used to restore the viability of the slowing economic processes and bring the system back to equilibrium.

Placed in a situation of rapidly changing environment, the social system in Bulgaria reacts slowly and with difficulty to the new and different situation. Even with the modern mechanisms for reporting the relevant changes, at least at this stage it is not able to respond adequately and acceptably to the pandemic situation caused by COVID 19.

Experts in this field expect this to some extent, because they are well aware of the mechanism of such decisions at national and European level. This is a process that is relatively long and not very flexible and practically does not meet the expectations of society.

The impact of many factors combined force our social system to make crisis and quick decisions. Everyone knows that making quick decisions is quite risky, because they are objectively not supported by an accurate and specific analysis of the situation and the seemingly positive results we expect sometimes have negative consequences.

Labour market fluctuations have already begun and they are seemingly obscured by the palliative measures of employers in order to maintain a longer state of equilibrium of the system, which objectively is no longer the case. Even unexplored processes move with such speed and are so clearly visible that we cannot help but discover the critical elements and moments. In this regard, there is a number of examples, such as the difficult movement of people and goods, limited access to a wide range of services, including guaranteed state ones (performed remotely or semi-remotely) at a slow pace, which not only makes it difficult, but even prevents the normal development of economic processes. This is just a glimpse of the already created situation and the detailed and deep analysis would give a much clearer and more accurate picture, which would certainly show a sufficiently critical phase.

Unfortunately, in crisis or emergency situations, we do not have enough time to do this particularly valuable work and to achieve a good analysis that will help make relevant, correct and right decisions.

It is accepted to consider the policies with which we intervene on the labour market as passive and active. In the first group there is a precise regulation, which in one form or another has been applied for more than 30 years. During this period, only the mechanism of determining the amount of unemployment benefits has changed and a larger amount of cash flows (again in the form of cash benefits) have been directed to one target group or another. In the period after 1989, for example, it was accepted that young graduates should also be supported and motivated with cash benefits for a certain period of time (up to 6 months) to find a suitable job. Subsequently, this mechanism was cancelled and the authorities sought other ways to motivate young people.

In moments of drastic increase in unemployment or mass layoffs of large groups of people and in order to "suppress" social discontent, the government paid off benefits for the entire period of time and it was expected to help create a small family business. Under difficult conditions this did not happen in practice and the expected impact on the primary local labour markets was either quite temporary or not realized at all. This mechanism is impractical in the current situation. Although if we seek similar solution, it should be developed to satisfy in the initial stage of the crisis those groups of people who could not cope without income - such type of benefit (survival aid).

Currently, this mechanism of passive support could be improved or partially changed, but the result of these actions will not be the expected one or will not respond at all to the emerged or emerging difficult social situation.

More interesting are the impacts we would expect from a change in active social policies. In the general sense of the term, they are expected to be flexible enough to respond to expectations, critical situations or negative processes occurring.

There is no time for a detailed analysis here either, but it is clear that it will affect almost all sectors of the economy directly or indirectly. The current tools of this so-called active policy relies primarily on a programmatic approach, with the possibility of a set of projects. This competitiveness created expectations and attitudes during different programme stages: for the projects to become better and more successful and for the result - more and more influential for the respective group of users. The question now is whether this is possible in the current situation and whether we have enough time to implement such a mechanism. 
Experience from the recent past of temporary employment programmes (which were much more important in small municipalities) showed that they were both an economic and a political tool to meet the need of employing a large number of people in community service and for them to receive certain incomes. This provided some reassurance to both government and local authorities that those who are long out of the labour market will have some employment. Another question is to what extent the usefulness of this activity was sufficiently justified.

Bulgaria still does not have registered mass layoffs of labour force on the labour market, but employers tend to use the possibilities of the labour legislation for collective paid leave or determining the situation as a downtime in manufacturing. This actually would work perfectly if it was clear that the critical situation would end in the foreseeable future. Even if we assume that in the next few months the pandemic situation will be controlled, then a recovery period will follow, which will not be less than a year and even more for some economic entities (Terziev, 2020e; 2020f).

Maintaining a relatively good situation on the labour market in Bulgaria is possible for a very short period and as these processes are already underway in full force, it can be expected that a highly problematic and critical situation will occur in early 2021 (Fig1-2) (2021).

\begin{tabular}{|c|c|c|c|c|c|}
\hline \multirow[t]{2}{*}{ Economic activity } & \multirow[t]{2}{*}{ STS activities code } & \multicolumn{4}{|c|}{ Quarters 2019} \\
\hline & & $\mathrm{I}$ & II & III & IV \\
\hline Industry (except construction) & B_TO_E36 & 574477 & 567699 & 561456 & 557697 \\
\hline Mining and quarrying & B & 20819 & 20739 & 20969 & 20550 \\
\hline \multicolumn{6}{|l|}{ of which: } \\
\hline Mining of coal and lignite & B05 & 8913 & 8813 & 8732 & 8285 \\
\hline Mining of metal ores & B07 & 6349 & 6331 & 6406 & 6385 \\
\hline Other mining and quarrying & B08 & 4470 & 4494 & 4723 & 4425 \\
\hline Manufacturing & C & 507460 & 500840 & 494434 & 491203 \\
\hline \multicolumn{6}{|l|}{ of which: } \\
\hline Manufacture of food products & C10 & 75433 & 74940 & 75204 & 74304 \\
\hline Manufacture of beverages & C11 & 11784 & 11647 & 11845 & 11454 \\
\hline Manufacture of tobacco products & C12 & 1477 & 1457 & 1469 & 1135 \\
\hline Manufacture of textiles & C13 & 11941 & 11697 & 11312 & 11190 \\
\hline Manufacture of wearing apparel & C14 & 78635 & 76905 & 74615 & 74799 \\
\hline Manufacture of leather and related products & C15 & 11347 & 10575 & 10148 & 10211 \\
\hline $\begin{array}{l}\text { Manufacture of wood and of products of wood } \\
\text { and similar materials, except furniture }\end{array}$ & C16 & 13887 & 13821 & 13642 & 13449 \\
\hline Manufacture of paper and paper products & C17 & 9310 & 9222 & 9015 & 8967 \\
\hline Printing and reproduction of recorded media & C18 & 8778 & 8739 & 8831 & 8828 \\
\hline Manufacture of chemicals and chemical products & $\mathrm{C} 20$ & 13705 & 13706 & 13316 & 13176 \\
\hline Manufacture of rubber and plastic products & $\mathrm{C} 22$ & 29703 & 29621 & 29361 & 29571 \\
\hline $\begin{array}{l}\text { Manufacture of other non-metallic mineral } \\
\text { products }\end{array}$ & $\mathrm{C} 23$ & 19931 & 19970 & 19618 & 19526 \\
\hline Manufacture of basic metals & C24 & 13013 & 12876 & 12843 & 12736 \\
\hline $\begin{array}{l}\text { Manufacture of fabricated metal products, except } \\
\text { machinery and equipment }\end{array}$ & $\mathrm{C} 25$ & 54856 & 54153 & 53491 & 52621 \\
\hline $\begin{array}{l}\text { Manufacture of computer, electronic and optical } \\
\text { products }\end{array}$ & $\mathrm{C} 26$ & 10640 & 10586 & 10351 & 10378 \\
\hline Manufacture of electrical equipment & $\mathrm{C} 27$ & 27476 & 27606 & 27279 & 27348 \\
\hline Manufacture of machinery and equipment n.e.c. & $\mathrm{C} 28$ & 32264 & 31918 & 31252 & 30552 \\
\hline $\begin{array}{l}\text { Manufacture of motor vehicles, trailers and semi- } \\
\text { trailers }\end{array}$ & C29 & 23078 & 21922 & 21100 & 21122 \\
\hline Manufacture of other transport equipment & C30 & 5416 & 5471 & 5486 & 5606 \\
\hline Manufacture of furniture & C31 & 19359 & 18891 & 18875 & 19095 \\
\hline Other manufacturing & C32 & 9922 & 9642 & 9881 & 9831 \\
\hline $\begin{array}{l}\text { Repair and installation of machinery and } \\
\text { equipment }\end{array}$ & C33 & 14757 & 14713 & 14745 & 14530 \\
\hline $\begin{array}{l}\text { Electricity,gas,steam and air conditioning } \\
\text { supply }\end{array}$ & $\mathbf{D}$ & 29898 & 29872 & 29844 & 29822 \\
\hline Water collection, treatment and supply & E36 & 16300 & 16248 & 16209 & 16122 \\
\hline Intermediate goods & MIG_ING & 165310 & 164598 & 162755 & 161430 \\
\hline Energy & MIG_NRG & 57539 & 57352 & 57203 & 56645 \\
\hline
\end{tabular}


Proceedings of SOCIOINT 2021 8th International Conference on Education and Education of Social Sciences 14-15 June, 2021

\begin{tabular}{|c|c|c|c|c|c|}
\hline Capital goods & MIG_CAG & 110766 & 108759 & 107014 & 105895 \\
\hline Durable consumer goods & MIG_DCOG & 29811 & 29423 & 29305 & 29632 \\
\hline Non-durable consumer goods & MIG_NDCOG & 211051 & 207567 & 205179 & 204095 \\
\hline Construction & $\mathbf{F}$ & 128550 & 130609 & 130246 & 128096 \\
\hline $\begin{array}{l}\text { Wholesale and retail trade and repair of motor } \\
\text { vehicles and motorcycles }\end{array}$ & G45 & 35696 & 35008 & 34843 & 35046 \\
\hline $\begin{array}{l}\text { Wholesale trade, except of motor vehicles and } \\
\text { motorcycles }\end{array}$ & G46 & 152789 & 153797 & 151943 & 151923 \\
\hline $\begin{array}{l}\text { Retail trade, except of motor vehicles and } \\
\text { motorcycles }\end{array}$ & G47 & 208764 & 210411 & 207670 & 209348 \\
\hline $\begin{array}{l}\text { Retail trade,exept of motor venicles, motorcycles } \\
\text { and fuel }\end{array}$ & G47_X_G473 & 194792 & 196565 & 194006 & 195617 \\
\hline Retail sale of food,beverages and tobacco & G47_FOOD & 82874 & 83438 & 81636 & 82198 \\
\hline Retail sale of non-food products & G47_NFOOD & 125890 & 126973 & 126034 & 127150 \\
\hline $\begin{array}{l}\text { Retail sale of non-food products except of motor } \\
\text { vehicles, motorcycles and fuel }\end{array}$ & G47_NFOOD_X_G473 & 111918 & 113127 & 112370 & 113419 \\
\hline Transportation and storage & $\mathbf{H}$ & 140818 & 141601 & 140877 & 138911 \\
\hline Land transport and transport via pipelines & $\mathrm{H} 49$ & 87926 & 87144 & 87068 & 86260 \\
\hline Water transport & $\mathrm{H} 50$ & 1312 & 1352 & 1359 & 1299 \\
\hline Air transport & $\mathrm{H} 51$ & 2195 & 2574 & 2567 & 2419 \\
\hline $\begin{array}{llll}\text { Warehousing and support } & \text { activities for } \\
\text { transportation }\end{array}$ & $\mathrm{H} 52$ & 30820 & 32098 & 31343 & 30281 \\
\hline Postal and courier activities & H53 & 18565 & 18433 & 18540 & 18652 \\
\hline Accommodation and food service activities & $\mathbf{I}$ & 106753 & 137367 & 115424 & 102684 \\
\hline Information and communication & $\mathbf{J}$ & 90343 & 91340 & 92506 & 93480 \\
\hline Publishing activities & J58 & 4818 & 4766 & 4678 & 4626 \\
\hline $\begin{array}{l}\text { Motion picture, video and TV programme } \\
\text { production, music publishing activities }\end{array}$ & J59 & 2027 & 1880 & 1928 & 1887 \\
\hline Programming and broadcasting activities & J60 & 2656 & 2581 & 2632 & 2617 \\
\hline Telecommunications & J61 & 19423 & 19128 & 18957 & 19018 \\
\hline $\begin{array}{l}\text { Computer programming, consultancy and related } \\
\text { activities }\end{array}$ & J62 & 50298 & 51739 & 52971 & 53991 \\
\hline Information service activities & J63 & 11121 & 11246 & 11340 & 11341 \\
\hline \multicolumn{6}{|l|}{ Other business services } \\
\hline Professional,scientific and technical activities & $\begin{array}{cc}\text { M69, } & \text { M702, } \\
\text { M71,M73, M74 }\end{array}$ & 65936 & 66204 & 64654 & 64149 \\
\hline Administrative and support service activities & $\begin{array}{l}\text { N78,N79,N80, } \\
\text { N812,N82 }\end{array}$ & 94951 & 95104 & 93007 & 92904 \\
\hline
\end{tabular}

Fig. 1. Employees under labour contract at the end of the quarter by economic activities in 2019 (2021)

\begin{tabular}{|c|c|c|c|c|c|}
\hline \multirow[t]{2}{*}{ Economic activity } & \multirow[t]{2}{*}{ STS activities code } & \multicolumn{4}{|c|}{ Quarters 2020} \\
\hline & & $\mathrm{I}$ & II & III & IV \\
\hline Industry (except construction) & B_TO_E36 & 553860 & 535856 & 535485 & \\
\hline Mining and quarrying & B & 21044 & 20439 & 20569 & \\
\hline \multicolumn{6}{|l|}{ of which: } \\
\hline Mining of coal and lignite & B05 & 8294 & 8032 & 7917 & \\
\hline Mining of metal ores & B07 & 6582 & 6324 & 6533 & \\
\hline Other mining and quarrying & B08 & 4571 & 4521 & 4516 & \\
\hline Manufacturing & C & 486873 & 469888 & 469531 & \\
\hline \multicolumn{6}{|l|}{ of which: } \\
\hline Manufacture of food products & C10 & 72232 & 71514 & 72865 & \\
\hline Manufacture of beverages & C11 & 11150 & 10846 & 10931 & \\
\hline Manufacture of tobacco products & C12 & 1295 & 1196 & 1174 & \\
\hline Manufacture of textiles & $\mathrm{C} 13$ & 11167 & 10664 & 11226 & \\
\hline Manufacture of wearing apparel & C14 & 72317 & 68735 & 66355 & \\
\hline
\end{tabular}


Proceedings of SOCIOINT 2021 8th International Conference on Education and Education of Social Sciences 14-15 June, 2021

\begin{tabular}{|c|c|c|c|c|}
\hline Manufacture of leather and related products & C15 & 9791 & 8848 & 8577 \\
\hline $\begin{array}{l}\text { Manufacture of wood and of products of wood and } \\
\text { similar materials, except furniture }\end{array}$ & C16 & 12772 & 12867 & 12773 \\
\hline Manufacture of paper and paper products & C17 & 8893 & 8364 & 8133 \\
\hline Printing and reproduction of recorded media & C18 & 8373 & 7700 & 7673 \\
\hline Manufacture of chemicals and chemical products & $\mathrm{C} 20$ & 13530 & 13707 & 13544 \\
\hline Manufacture of rubber and plastic products & $\mathrm{C} 22$ & 29381 & 28392 & 28663 \\
\hline Manufacture of other non-metallic mineral products & $\mathrm{C} 23$ & 19701 & 19238 & 19306 \\
\hline Manufacture of basic metals & $\mathrm{C} 24$ & 12969 & 12536 & 12467 \\
\hline $\begin{array}{l}\text { Manufacture of fabricated metal products, except } \\
\text { machinery and equipment }\end{array}$ & $\mathrm{C} 25$ & 52853 & 51233 & 51224 \\
\hline $\begin{array}{l}\text { Manufacture of computer, electronic and optical } \\
\text { products }\end{array}$ & $\mathrm{C} 26$ & 10145 & 9933 & 10009 \\
\hline Manufacture of electrical equipment & $\mathrm{C} 27$ & 27431 & 26245 & 25668 \\
\hline Manufacture of machinery and equipment n.e.c. & C28 & 31248 & 29898 & 29598 \\
\hline $\begin{array}{l}\text { Manufacture of motor vehicles, trailers and semi- } \\
\text { trailers }\end{array}$ & C29 & 22617 & 21275 & 22198 \\
\hline Manufacture of other transport equipment & C30 & 5336 & 5096 & 5350 \\
\hline Manufacture of furniture & C31 & 18195 & 17368 & 17731 \\
\hline Other manufacturing & C32 & 9907 & 9111 & 9111 \\
\hline $\begin{array}{l}\text { Repair and installation of machinery and } \\
\text { equipment }\end{array}$ & C33 & 14801 & 14268 & 14184 \\
\hline $\begin{array}{l}\text { Electricity,gas,steam and air conditioning } \\
\text { supply }\end{array}$ & $\mathbf{D}$ & 29893 & 29658 & 29520 \\
\hline Water collection, treatment and supply & E36 & 16050 & 15871 & 15865 \\
\hline Intermediate goods & MIG_ING & 162576 & 158024 & 157915 \\
\hline Energy & MIG_NRG & 56704 & 56023 & 55766 \\
\hline Capital goods & MIG_CAG & 107068 & 102770 & 103035 \\
\hline Durable consumer goods & MIG_DCOG & 28436 & 27039 & 27650 \\
\hline Non-durable consumer goods & MIG_NDCOG & 199076 & 192000 & 191119 \\
\hline Construction & $\mathbf{F}$ & 123772 & 125336 & 125272 \\
\hline $\begin{array}{l}\text { Wholesale and retail trade and repair of motor } \\
\text { vehicles and motorcycles }\end{array}$ & G45 & 34471 & 33837 & 34013 \\
\hline $\begin{array}{l}\text { Wholesale trade, except of motor vehicles and } \\
\text { motorcycles }\end{array}$ & G46 & 151495 & 149434 & 149342 \\
\hline $\begin{array}{l}\text { Retail trade, except of motor vehicles and } \\
\text { motorcycles }\end{array}$ & G47 & 203265 & 203188 & 202352 \\
\hline $\begin{array}{l}\text { Retail trade,exept of motor venicles,motorcycles } \\
\text { and fuel }\end{array}$ & G47_X_G473 & 189915 & 189784 & 189028 \\
\hline Retail sale of food,beverages and tobacco & G47_FOOD & 79954 & 82609 & 81153 \\
\hline Retail sale of non-food products & G47_NFOOD & 123311 & 120579 & 121199 \\
\hline $\begin{array}{l}\text { Retail sale of non-food products except of motor } \\
\text { vehicles, motorcycles and fuel }\end{array}$ & G47_NFOOD_X_G473 & 109961 & 107175 & 107875 \\
\hline Transportation and storage & $\mathbf{H}$ & 140073 & 136979 & 137076 \\
\hline Land transport and transport via pipelines & $\mathrm{H} 49$ & 87308 & 84723 & 85184 \\
\hline Water transport & $\mathrm{H} 50$ & 1180 & 1140 & 1124 \\
\hline Air transport & $\mathrm{H} 51$ & 2375 & 2143 & 2069 \\
\hline $\begin{array}{l}\text { Warehousing and support activities for } \\
\text { transportation }\end{array}$ & H52 & 30549 & 30114 & 29849 \\
\hline Postal and courier activities & H53 & 18661 & 18859 & 18850 \\
\hline Accommodation and food service activities & $\mathbf{I}$ & 81864 & 88891 & 89664 \\
\hline Information and communication & $\mathbf{J}$ & 98821 & 97386 & 99031 \\
\hline Publishing activities & J58 & 4057 & 3840 & 3615 \\
\hline $\begin{array}{l}\text { Motion picture, video and TV programme } \\
\text { production, music publishing activities }\end{array}$ & J59 & 2338 & 1826 & 1934 \\
\hline
\end{tabular}


Proceedings of SOCIOINT 2021 8th International Conference on Education and Education of Social Sciences 14-15 June, 2021

\begin{tabular}{|l|l|l|l|l|l|}
\hline Programming and broadcasting activities & $\mathrm{J} 60$ & 2656 & 2547 & 2563 & \\
\hline Telecommunications & $\mathrm{J} 61$ & 19008 & 18984 & 19233 & \\
\hline $\begin{array}{l}\text { Computer programming, consultancy and related } \\
\text { activities }\end{array}$ & $\mathrm{J} 62$ & 59238 & 58854 & 60003 & \\
\hline Information service activities & $\mathrm{J} 63$ & 11524 & 11335 & 11683 & \\
\hline Other business services & & & & & \\
\hline Professional,scientific and technical activities & $\begin{array}{l}\text { M69, } \\
\text { M71,M73, M74 M702, }\end{array}$ & 66263 & 64737 & 64582 & \\
\hline Administrative and support service activities & $\begin{array}{l}\text { N78,N79,N80, } \\
\text { N812,N82 }\end{array}$ & 93746 & 90305 & 90677 & \\
\hline
\end{tabular}

Fig. 1. Employees under labour contract at the end of the quarter by economic activities in 2020 (2021)

Undoubtedly, people's lives and health are of paramount importance, but it is also indisputable that these people must continue to live in a certain social comfort. Both circumstances occur whether or not we anticipate them and whether we are prepared for them. And if at the moment we have serious problems with limiting the spread of a disease, trying to protect our health system from collapse, we must not forget that this system is also part of the functioning social system and ongoing social processes. We need to think very quickly about all the other elements of our social system. It is clear to specialists, as well as to everyone else, that these elements cannot function on their own. Obviously, we take crisis decisions and measures in only one direction - the healthcare system. We have left the other elements of this system to function in the usual way and rhythm. Even with delayed action, the processes will occur in the other elements of the system, and they are no less vulnerable, and in some cases quite the oposite.

Here is another element of the action of the social system - the education in its remote form. Some politicians and even experts say that we have made a leap that would cost us at least ten years in the normal course of events. This comment is related to the fact that the system of primary, secondary and higher education operates remotely, or at least this is the expectation of the leaders of these systems. It is difficult to accept that this "leap" is as successful as it is described to us, and without disputing the possibilities of digital education and distance learning, it should be noted that in addition to technological and technical training the so called social preparation is required - how and in what way to present the material that needs to reach the user digitally - a pupil, a student, a worker or in the most general sense an employee. Goodlooking interactive methods, interactive classrooms, shared electronic spaces in general are an option, but not always the best one. Both parties must be well prepared for both the transmission and acceptance of knowledge. We are not talking about the transmission of information, but about knowledge. If this process would seem quite easy and pragmatic for people who have enough experience in this direction, then traditional teachers and not only to some extent have a lack of skills in this direction (Terziev, 2017).

\section{CONCLUSION}

In recent years, much research has been done on the processes of social adaptation, which are quite difficult and not always successful. We have exeprienced such a not very pleasant outcome in Bulgaria in the process of reducing the number of Bulgarian armed forces and the subsequent dismissals of tens of thousands highly qualified specialists, who afterwards had not managed to successfully realize themselves on the primary labour market. So after a process of social isolation, which may last another month, two or maybe more, not a small percentage of people will need an adaptive process and specialized help, which may bring new critical situations and negative consequences.

This is just a hint of the whole set of problems that will arise together with the already existing qualitatively new and different social process, which requires very precise and measured action and the expertise of a large number of specialists who need to develop a crisis action plan in this direction. Obviously the ones developed at the moment do not work or are only partially applicable.

\section{REFERENCE LIST}

Terziev, V. (2020). The national employment plan in Bulgaria - policies, priorities and necessary changes due to COVID-19. // Economic Archive, Dimitar A. Tsenov Academy of Economics, Svishtov, 2020, 
(3), pp. 41-54, ISSN 0323-9004.

Terziev, V. (2020a). COVID-19 and the National employment plan in Bulgaria - analysis and opportunities for change. // Economic Archive, Dimitar A. Tsenov Academy of Economics, Svishtov, 2020, (3), pp. 55-70, ISSN 0323-9004.

Terziev, V. (2020b). The Bulgarian labor market in a period of extraordinary crisis from the COVID-19 pandemic. // 18th RSEP International Economics, Finance \& Business Conference - Virtual/Online 2627 August 2020, Kadir Has University, Istanbul, Turkey, pp.111-115, ISBN: 978-605-06961-58/September 202.

Terziev, V. (2020c). The change in our new social development. // 27th International scientific conference Knowledge for sustainability (Struga, N. Macedonia), Knowledge - International Journal Vol. 41.1, Institute of Knowledge Management, Skopje, N. Macedonia, 41, 2020, 1, pp. 77-80, ISSN 1857-923X (for e-version), ISSN 2545 - 4439 (for printed version).

Terziev, V. (2020d). Bulgarian universities and the crisis situation created by COVID-19. // 59th International Scientific Conference on Economic and Social Development, Economic and Social Development (Book of Proceedings), Cakovec, Croatia, 2020, pp.113-117, ISSN 1849-7535.

Terziev, V. (2015). Analyses of Labor Market Development in the Republic of Bulgaria and the influence of the transition period, TSRNS, Novosibirsk, Rossiya, 30.04.2015 (Terziev, V. Analyses of Labor Market Development in the Republic of Bulgaria and the influence of the transition period, ЦРНC, Новосибирск, Россия, 30.04.2015).

Terziev, V. (2020e). Labour market policies in Bulgaria during periods of crisis. // 54th International Scientific Conference on Economic and Social Development, Novosibirsk, 21-22 May 2020, Economic and Social Development (Book of Proceedings), pp. 92-101, ISSN 1849-7535.

Terziev, V. (2020f). Change in the employment action plans during crisis. // 54th International Scientific Conference on Economic and Social Development, Novosibirsk, 21-22 May 2020, Economic and Social Development (Book of Proceedings), pp. 366-376, ISSN 1849-7535.

National Statistical Institute of the Republic of Bulgaria, (2021), https://www.nsi.bg/ (02/2021).

Terziev, V. (2017). Politiki i instrumenti za sotsialno razvitie, Innovations and Sustainability Academy, 2017, ISBN 978-619-7246-14-8, 318 str. (Terziev, V. Политики и инструменти за социално развитие, Innovations and Sustainability Academy, 2017, ISBN 978-619-7246-14-8, 318 стр). 